\title{
AN ANALYSIS OF POLICY COMPATIBILITY BETWEEN CONVENTIONAL INSURANCE AND ISLAMIC INSURANCE POLICIES: A STUDY OF CONCEPTUAL AND OPERATIONAL DIFFERENCES
}

\author{
Seyed Mohamed Mohamed Mazahir ${ }^{1}$ \\ Asmak Ab Rahman ${ }^{2}$ \\ Mohammad Ismath Ramzy ${ }^{3}$
}

\begin{abstract}
The aim of this study is to compare and contrast conventional insurance policies from Islamic insurance policies (takäful) using a qualitative method consisting of a descriptive and narrative analysis. This study makes a case for takäful as complimentary to conventional insurance. However, the differences between Islamic and conventional insurance are found mainly in their conceptual framework, how governments regulate them, corporate ownership and financing, management, accounting systems, and how
\end{abstract}

1 PhD Candidate, Academy of Islamic Studies, University of Malaya, 50603 Kuala Lumpur, Malaysia; Senior Lecturer, Islamic Studies, South Eastern University of Sri Lanka, Oluvil 32360 Sri Lanka, mazahirsmm@seu.ac.lk

2 Senior Lecturer, Department of Shariah and Economics, Academy of Islamic Studies, University of Malaya, 50603 Kuala Lumpur, asmak@um.edu.my

3 Senior Lecturer, Department of Educational Foundations and Humanities, Faculty of Education, University of Malaya, 50603 Kuala Lumpur, ismathramzy@um.edu. my 
premiums are invested. Both conventional and Islamic insurance are similar in this regard and are both utilized as safety nets in the event of unforeseen incidents. However, to maintain the integrity of Islamic law and Muslim society, insurance practices must be tailored to further comply with the Shariah principles.

Keywords: takäful, conventional, insurance, Islamic, difference, similarity

\section{INTRODUCTION}

Insurance is a financial arrangement which redistributes the costs of unexpected losses and is a risk-sharing agreement between two parties. In this arrangement, one party (the insurer) agrees to financially assist another party (the insured), through a contract, against certain losses specified by said contract's policy. As such, insurance is an economic tool by which individuals and organizations can transfer financial risks and losses to others, in exchange for a fee (premium). ${ }^{4}$

Insurance has become essential for individuals and business organizations in the contemporary world for ensuring a functioning economy and social stability. Throughout human history, the concept of insurance has been implemented in some form or another as civilizations established themselves. This is especially the case with regard to natural disasters, where societies would ensure the continued existence of its members through communal charity. This type of insurance has survived to the present day in some parts of the world where modern insurance systems have yet to be implemented. ${ }^{5}$

Risks in life have increased with rapid development and industrialization. The former has been a revolution in socio-economic life which has spread globally; developments in faster transportation, machinery for production and their subsequent pollutants, new fuels, radiation, weapons of war, and the congestion of 'super-cities' have all contributed to an increase in injury and disease. Even though, the development of health sector in the global context leads to the improvement of wellbeing, so that there is an increase in lifespan and decrease in mortality rate of the people.

To alleviate the seriousness of consequences from these unexpected perils and to protect the economy from the loss, the prototypical and restricted

4 Dorfman, M.S., Introduction to Insurance (Englewood Cliffs, USA: Prentice-hall, 1978), 3 .

5 Anscombe, V., 'A Brief History of Insurance throughout the Ages,' Columbus Direct, http://www.columbusdirect.com/content/insurance-history/, accessed 16 December 2016. 
concept of insurance was introduced from the very beginning. However, it has developed today to the extent of becoming an essential aspect of life and society in the modern world. The first official insurance system emerged in the $17^{\text {th }}$ century in London and developed over a 300 year period.

Insurance is initially originated as a commercial instrument. Due to the Great Fire of London, "Fire Insurance," emerged. The outcome of the Great Fire led to the creation of the first insurance company by Dr. Nicholas Bardon. To protect the buildings and houses it was established and the Insurance Office started the teams of actual firefighting. The badges were introduced by the Insurance Office known as firemarks for its insured properties; its teams of firefighting extinguished fires solely in buildings with the firemarks. Afterwards other insurance companies soon followed and employed their own fire departments. ${ }^{6}$

However, insurance as a commercial instrument only became popular among Muslims in the latter part of the $20^{\text {th }}$ century. Even though, Muslims have known about the concept in different forms throughout Islamic history, they left this legacy for due to several reasons such as the ignorance on the Islamic perspective of the human life, lack of knowledge in implementation of Islamic doctrines as per the improvement in human civilization. However, with the revival of Islamic thought around the 1970's, awareness of 'halāl' (permissibility) practices and institutions, particularly after the issuance of a fatwa (legal opinion) $)^{7}$ on the prohibition of conventional insurance in Islam, they began to study the insurance system from an Islamic perspective. ${ }^{8}$ For this purpose, Islamic scholars critically examines the theories and operations of the conventional system and attempted to formulate an alternative system

6 Buckham, David, Jason Wahl \& Stuart Rose, Executive's Guide to Solvency II (Cary, North Carolina: SAS Institute Inc., 2010), 5 \& 6.

7 A number of fatawwa (legal opinions) were issued on the prohibition of conventional insurance around the Muslim world. Abu-Hussain, M. F., Muhamad, N. H. N., \& Hussain, M. Y. M. (2014) compiled these fatwas as (1) Fiqh Council of the Muslim World League (2) Islamic Research Institute of Al-Azhar University in 1965 (3) Grand Council of 'Ulama of Saudi Arabia (4) Majlis Tahqūqāt al-Sharī'ah Lucknow, India (5) Al Majma' al-Fiqhi al-Islami of OIC in 1975 (6) Council of Islamic Ideology, Pakistan (7) International conference on Islamic Economic in 1976, and (9) European Council for Fatwa. See: Abu-Hussain, M. F., Muhamad, N. H. N. \& Hussain, M. Y. M., 'Takāful (Islamic Insurance) Industry in Malaysia and the Arab Gulf States: Challenges and Future Direction,' Asian Social Science, 10/21 (2014): 26-34.

8 Abu-Hussain, M. F., Muhamad, N. H. N. \& Hussain, M. Y. M., 'Takāful (Islamic Insurance) Industry in Malaysia and the Arab Gulf States: Challenges and Future Direction,' 26-34. 
based on Islamic values and principles. They named this alternative system of insurance takāful. ${ }^{9}$

The takâful system emerged around concerns for social solidarity, cooperation, and mutual risks sharing. As per practice of takäful, a part of contributions (premiums) under the takäful system falls under the category of 'donation' to ensure a liability with the focus on societal welfare. The remaining part of the premium is considered muda arabah ${ }^{10}$ (profit and loss sharing venture). This mudārabah part comprises tabarru ${ }^{\text {"11 }}$ (donation or charity) and mutual share of losses. The loss or damage that may be inflicted upon any member under the contract will be covered by the funds they contributed and agreed upon. In this way, the Islamic insurance system minimize the element of absolute uncertainty. It is also noteworthy that the Islamic insurance system has introduced new and effective models in recent times, such as wakălah ${ }^{12}$ (agency) and waqf, ${ }^{13}$ to minimize absolute uncertainty loss.

\section{OBJECTIVE OF THE STUDY}

1. To analyse the conceptual and operational differences between conventional insurance and takāful insurance.

2. To find a mutual relationship between the conventional insurance and Islamic Insurance (takāful).

$9 \quad$ Islamic insurance is also known by several other names, including 'co-operative insurance' and 'halāl insurance'.

10 Mudārabah (profit and loss sharing) - The parties are the rabb al-māl (investor) who solely provides the capital, and the mudāarib (entrepreneur) solely manages the project. If the venture is profitable, the profit will be distributed based on a preagreed ratio. If the business incurs a loss, it will be borne solely by the provider of the capital.

11 Tabarru ' Donation, charity. A contract where a participant agrees to donate a predetermined percentage of his contribution (to a takâful fund) to provide assistance to fellow participants. In this way he fulfils his obligation of joint guarantee and mutual help should another participant suffer a loss. This concept eliminates the element of gharar from the takäful contract.

12 Wakālah - Agency. A takäful practical model includes a representative who is appointed to undertake transections on behalf of another person. The takāful operator earns a fee for services borne by the participants. The fee may vary based on the performance of the takâful operator.

13 Waqf - An endowment or a charitable trust set up for Islamic purposes (usually for education, mosques, or for the poor). It involves investing in a property in perpetuity so that it cannot be sold, inherited, or donated to anyone. 
An Analysis of Policy Compatibility Between Conventional Insurance and Islamic Insurance Policies: A Study of Conceptual and Operational Differences

\section{RESEARCH QUESTIONS}

1. Are there are any conceptual and operational differences between conventional insurance and takäful?

2. Is there any compatibility between conventional insurance and takäful?

\section{METHODOLOGY}

This study is built upon a qualitative methodology which primarily consists of the descriptive and narrative analysis. Thus, it is based on data which have been collected from several secondary sources. Said data have been collected through written documents - books, journal articles, and reports in addition to web-based documents. The qualitative variables identified in this study are: 'conventional insurance' and 'takäful'. Most of the secondary data used in this study is in the English language.

\section{LITERATURE REVIEW}

Mohd Shril Matsawali ${ }^{14}$ examined the preferences and understanding of the general public in Brunei regarding takâful and conventional insurance in order to identify any determinants that made the two contradictory. Random sampling was implemented and on-line questionnaires were distributed among residents of Brunei Darussalam in order to collect the secondary qualitative data. It was found that the majority of respondents did not understand what takafful was. The questionnaire further revealed that preference for conventional insurance was overrepresented. Finally, it was proposed and recommended that the general public should be made aware of takäful institutions so as to increase their knowledge and understanding of takâful.

Nico P. Swartz and Pieter Coetzer ${ }^{15}$ aimed to find the greatest challenges of the Islamic insurance-takāful among Muslims using a descriptive analysis. They found that misconceptions among the general population - Muslims included - was one of the greatest obstacles in the way of practicing takäful in multiracial countries. Other challenges included the lack of development

14 Mohd Shril Matsawali et al., 'A Study on Takäful and Conventional Insurance Preferences: The Case of Brunei,' International Journal of Business and Social Science, 3/22 (Special Issue-November 2012): 163-176.

15 Nico P. Swartz \& Pieter Coetzer, 'Takâful: An Islamic Insurance Instrument,' Journal of Development and Agricultural Economics, 2/10 (2010): 333-339. 
of banking institutions and the absence of supplying takâful products in conventional markets. Further, they found that in the multiracial country of Malaysia, takäful products had attracted more non-Muslim customers as their awareness of Islamic insurance was higher than even the Muslim majority. However, they concluded that the positional of attracting Muslims and nonMuslims towards takäful was promising, despite the challenges.

Maher Mushtaq Hussai and Ahmad Tisman Pasha ${ }^{16}$ aimed to find similarities between conventional insurance and takâful through the use of a descriptive analysis and the aid of secondary sources. Their methods were sufficient to delineate clear conceptual and operational differences. They found that takaful contrasted with conventional insurance in practice in so many ways. Finally, after having analyzed the major conceptual and operational paradigms, they concluded that conventional insurance was not in line with the Shariah.

Using a qualitative analysis, Hussein A Abdou ${ }^{17}$ aimed to differentiate between the performances of takäful and conventional life insurance policies in Malaysia with a view to inform the decisions of stakeholders in connection with insurance. He used variables such as Gross Domestic Product (GDP), Consumer Price Index (CPI) and Treasury Bill Rate (TBR) in his descriptive analysis and logistic regression models. He collected data for the study from the annual reports of relevant institutions. His study revealed that the conventional performance of the insurers was better than takâful insurance companies in connection with profitability and risk measurement, but takâful insurance surpassed conventional insurance in respect of premium to surplus ratio. Further, his empirical study showed that unlike conventional insurance, the growth of takäful companies was not affected by the macro-economic variables.

Merazga Hachemi et al. ${ }^{18}$ aimed to compare the differences between takäful and conventional insurance with regard to conceptual frameworks, comparative advantages, and applications in the market using the qualitative research based

16 Mher Mushtaq H., \& Ahmad Tisman P., 'Conceptual and Operational Differences between General Takäful and Conventional Insurance,' Australian Journal of Business and Management Research, 1/8 (2011): 23-28.

17 Hussein A. Abdou., 'A Comparative Study of Takāful and Conventional Insurance: Empirical Evidence from the Malaysian Market,' Insurance Markets and Companies: Analyses and Actuarial Computations, 4/1 (2014): 23-35.

18 Merazga Hachemi, A.A.M. et al., 'Takâful and Conventional Insurance: A Comparative Study,' International Journal of Management Sciences, 2/12 (2014): 543-551. 
An Analysis of Policy Compatibility Between Conventional Insurance and Islamic Insurance Policies: A Study of Conceptual and Operational Differences

on the descriptive analysis. He found that there were major differences between takäful and conventional insurance in protecting individuals and society.

\section{GAP OF THE STUDY}

Even though many researchers have studied the compatibility of conventional insurance with Islamic insurance, the connection has not been deeply analysed nor has it been made clear which is better. Conversely, this study is more ambitious. Accordingly then, this study focusses on the relationship between the two insurances and on clearing any confusion.

\section{DEFINITION OF INSURANCE}

Oxford online dictionary defines "insurance as an arrangement by which a company or the state undertakes to provide a guarantee of compensation for specified loss, damage, illness, or death in return to the payment of a specified premium." 19

Moreover, insurance is a risk transferring mechanism whereby the individual or the business enterprise can shift some of the uncertainties to others. Under this assumption, all people desire to live in a healthier, comfortable, and peaceful condition. To meet these standards, different enterprises provide various services; they innovate the insurance products to undertake more risks and uncertainties. ${ }^{20}$

Insurance provides the peace of mind and protection to trade and commit to industry, which ultimately contributes towards human progress. Thus, insurance is a mechanism to contribute to the growth of economic, social, and technological progress. Without insurance, the economic and social activities of the world would come to a grinding halt, or at least slowed substantially. ${ }^{21}$

There are two types of insurance today. One is conventional insurance and the other is takâful - an Islamic alternative to the conventional model.

19 Fowler, F. G., 'Insurance', The Concise Oxford Dictionary of Current English, https://en.oxforddictionaries.com/definition/insurance, accessed 18 December 2016.

20 Farooq, S.U., Chaudry, T.S., Fakhr-e-Alam \& Ahmad, G., 'An Analytical Study of the Potential of Takâful Companies', European Journal of Economics, Finance and Administrative Sciences, 20 (2010): 54-75.

21 Farooq, S.U., Chaudry, T.S., Fakhr-e-Alam \& Ahmad, G., 'An Analytical Study of the Potential of Takâful Companies', 54-75. 
As discussed above, the conventional system of insurance developed and stretched to all forms of business institutions as well as monetary transactions.

\section{Conventional Insurance}

Conventional insurance is a system of collecting premiums from policyholders and investing them in interest-based activities. The governments and private corporations own insurance companies in order to ensure secured economic development and service. These companies provide compensation to any affected members during loss or difficulties. However, the policyholder will never receive any payment or incentives if there are no unfortunate incidents within a specified time, as defined in the policy agreement. This is the common practice in conventional insurance regardless of various packages and promotions offered.

\section{Takāful (Islamic Insurance)}

However, the takâful system is different from the conventional insurance system in terms of concept and operation. The elements that contradict the Islamic Shariah in conventional insurance are: interest, uncertainty, and gambling - issues which have encouraged Muslim scholars to think up an alternative system that ensures social and mutual protection for the 1.8 billion Muslim population. ${ }^{22}$ But muslimpopulation.com indicates that the current Muslim population in the planet is 2.14 billion. $^{23}$

The word takâful is derived from the Arabic root-verb "kafala", which means guarantee, bail, warrant or an act of securing one's need. ${ }^{24}$ Therefore, takâful, in its reciprocal form, means a joint guarantee, whereby a group of participants agree to mutually guarantee each other against a defined loss. In the context of insurance, takâful refers to an arrangement for a mutual indemnity in providing protection and compensation to the participants who suffered from perils or hazards. ${ }^{25}$ Azeem Pirani states that this (cooperative) method

22 Michael Lipka, 'Muslims and Islam: Key Findings in the U.S. and Around the World,' Pew Research Centre, http://www.pewresearch.org, accessed on 07 February 2017.

23 Muslim Population, "Muslim Population in the World," http://www. muslimpopulation.com/, accessed on 13 July 2017.

24 Engku Rabiah Adawiah, E.A., \& Hassan Scott, P.O., Essential Guide to Takāful (Islamic Insurance) (Kuala Lumpur: CERT Publications Sdn. Bhd., 2008), 3.

25 Engku Rabiah Adawiah, E.A., \& Hassan Scott, P.O., Essential Guide to Takāful, 3. 
An Analysis of Policy Compatibility Between Conventional Insurance and Islamic Insurance Policies: A Study of Conceptual and Operational Differences

of risk mitigation has been used for centuries, albeit under different names. ${ }^{26}$ Prior to the advent of takâful, the most common type of Islamic insurance has been 'mutual insurance' which, although similar, is not identical.

The origin of Islamic insurance can be traced from the period of jāhiliyyah, before the era of the Prophet Muhammad (PBUH), particularly in the practices of ' $\bar{a}$ qilah, ${ }^{27}$ or mutual co-operation. ${ }^{28}$ This practice continued during the period of the Prophet (PBUH $)^{29}$ and it was included in the constitution of al-Madinah in 622 A.D. ${ }^{30}$ Moreover it was even made mandatory in some cases during the period of the second caliph 'Umar. ${ }^{31}$

In $19^{\text {th }}$ century, Ibn 'Ābidīn (1784-1836), a scholar from Hanafī school of thought, was the first who came up with the meaning, concept, and legal entity of the Islamic insurance contract. He was also the first person who repeated the word 'insurance' in a legal context and not just in customary practice. ${ }^{32}$ In 1906, Muhammad Baqīt, the mufti of Egypt, approved the idea

26 Azeem Pirani, 'Takāful: What's it all about?', http://www.pakqatar.com.pk/ downloads/articles/takaful-what-is-it-all-about.pdf, accessed on 13 June 2014.

27 It was a common practice of the ancient Arab tribes that, if any member of a tribe was killed by a member of another tribe, that the heir of the victim would be paid an amount of blood money as compensation by the close relatives of the killer. Those close relatives of the killer, called ' $\bar{a} q i l a h$ ', were supposed to pay the blood money on behalf of the killer.

28 Klingmuller, E., 'The Concept and Development of Insurance in Islamic Countries', Islamic Culture, XLIII (1969), as quoted by Mher Mushtaq H., \& Ahmad Tisman P., 'Conceptual and Operational Differences between General Takäful and Conventional Insurance,' 25.

29 Narrated by Abū Hurayrah RA: He said that once two women from 'Hudhayl' clashed. One of them hit the other with a stone which killed her and the foetus in the victim's womb. The heirs of the victim brought an action to the court of the Holy Prophet (PBUH) who gave a verdict that the compensation for the foetus to be a male or female slave while the compensation for the victim woman is a blood money (diyāt) to be paid by the 'äqilah' (the paternal relatives) of the killer. See Ibn Ḥajar al-'Asqalānī, Fath al-Bārī bi Sharḥ Șaḥīh al-Bukhārī, vol. 12 (Cairo, Egypt: Dār al-Hadīth, 2004), 289, 290, no. hadìth 6910.

30 Ma'sum Billah, M., Islamic Insurance (Takâful) (Selangor: 'Ilmiah Publisher, 2003), 3.

31 Muslehuddin, M., Insurance and Islamic Law, $5^{\text {th }}$ ed. (Lahore: Islamic Publications Ltd., 1990), 30.

32 al-Haskafī, A.M.A., Radd al Mukhtār 'alā al-Durr al-Mukhtār Hāshiyah Ibn 'Ābidin, vol. 6 (Beirūt: Dār al-Ma'rifah, 2000), 268. 
of insurance which was explained by Ibn 'Ābidīn..$^{33}$ In the twentieth century, the well-known Islamic jurist, Muhammad 'Abduh issued two 'fatawa' $\bar{a}^{34}$ on legalizing insurance practices. His opinion is based on Islamic principles that show why life insurance is permissible. One of the fatw $\bar{a}$ views the relationship between the insured and the insurance group as a mudārabah (profit and loss sharing venture) contract. The other fatwa legitimizes a transaction similar to endowment life insurance. ${ }^{35}$

In the later part of the $20^{\text {th }}$ century, Islamic insurance companies came to exists in several places in the form of Shariah compliant insurance. At present, according to A.M. Best, the market has now grown to comprise roughly 200 companies, including 'window'36 operations affiliated with conventional insurers. It provides various takāful products to all including non-Muslims. ${ }^{37}$

Takāful is characterised by three aspects of mutuality, namely: mutual help, mutual responsibility, and mutual protection from losses. The person seeking protection participates in a scheme of co-operation with other participants to mutually insure one another. The company that runs the scheme is not the insurer, but is merely an institution which provides the entrepreneurial and administrative skills required to bring the participants together, to collect the contributions, and to invest. Obaidullah states that donations from all participants are accumulated into a common fund called a tabarru ' fund' or 'risk fund', from which compensation or indemnification is paid to participants suffering a defined loss. ${ }^{38}$

This study intends to analyse the conceptual and operational differences between conventional insurance and takâful. According to the available review of related literature, there are studies focussing on the concepts and operations of conventional insurance and takâful. However, most of them have failed to clarify to Muslims regarding takâful, particularly due to a lack of understanding in its operation. Therefore, this study bridges this gap by discussing the very concepts and operations of insurance and takâful comparatively and analytically.

\footnotetext{
33 Muslehuddin, M., Insurance and Islamic Law, 150.

34 A Fatwa $\bar{a}$ is an Islamic legal opinion issued by an expert in religious law (muftì), pertaining to a specific issue, usually at the request of an individual or judge to resolve an issue where Islamic jurisprudence ( $f i q h)$ is unclear.

35 Ma'sum Billah, M., Islamic and Modern Insurance, 9.

36 Window is called a department of a conventional bank offering Islamic financial services.

37 A.M. Best, Takāful Review (New Jersey: A.M. Best Company Inc., 2013), 13.

38 Obaidullah, Islamic Financial Services (Jeddah, KSA: Islamic Economic Research Centre, King Abdulaziz University, 2005), 281 \& 282.
} 
An Analysis of Policy Compatibility Between Conventional Insurance and Islamic Insurance Policies: A Study of Conceptual and Operational Differences

\section{DISCUSSION AND ANALYSIS}

The similarities and differences between conventional insurance and takāful can be evaluated from various perspectives. As such, Islamic and the conventional insurance systems are compared on the basis of concept and practice in terms of their governing principles, goals, risks, ownership, monitoring committees, unlawful elements, operations, contracts, investments, surpluses, forfeitures, and encouragement for wellbeing.

\section{Governing Principles}

From the perspective of governance, the takaful principles have their roots in Shariah while the principles in conventional insurance are derived from anecdote and empirical studies. The governing principles in takāful trace their origins mainly from the Qur'ān, the practices of the Prophet (PBUH), ijma ' (consensus of the Muslim scholars), and qiyās (deductive analogy). ${ }^{39}$ In addition to these primary sources, Muslim jurists and scholars have added secondary sources such as qawl al-șahäbah (legal opinions of the companions of the Prophet), al-mașlahah al-mursalah (public interests), and al-'urf (custom and traditions of the community). Hence, takâful reflects the Will of God, justice, broad vision, and God's guidance on human relationship with their fellow man. However, in conventional insurance, rules and regulations are made from experts' opinions and public interests. Thus, the majority of the rules and regulations in conventional insurance reflect people's perception on life and with their fellow human beings. For instance, the insurance system developed in Western society reflects Western thought on life and society. The Western thought of human life is based on feeling oneself as an element of the Divine, linear view of the universe and life, based on the philosophy of Christianity in which everything has its beginning and the end, life is a service (to the God, money, business, etc.), outer-world dependent, and self-dedication to the goal (life vision, success, happiness, etc.)

It is because; the Acts of parliament, judicial precedents and the customs of the Western society provides the sources for rules and regulations to conventional insurance system. Therefore, takaful system is different from conventional insurance in term of governing principles though both insurance systems try to achieve similar objectives. This aspect has to be adequately reflected on the takâful to clear the confusion.

39 Umar Chopra, M., The Islamic Welfare State and its Role in the Economy (Leicester: The Islamic Foundation, 1979), 11-20. 
The nature of the governing principles of takâful differ from conventional insurance as all the operational activities of the former are derived from and compatible with the Shariah. Accordingly, the instrumental operational activities of takâful has been enacted on the basis of al-mudarabah, which is known as a technique of profit and loss sharing - an alternative provision to interest $(r i b \bar{a})$.

In terms of government monitoring of takâful companies, the regulators of the industry are likely to seek support and assistance from the practice of the administrative and governing principles of conventional insurance companies. Thus, there are possibilities of using conventional principles and rules of calculating premium that can be applied by the regulators of the takâful companies. However, this sort of administrative process can be mediated by the Shariah. In addition, the governing principles of al-Siyāsah al-Shar 'iyyah should be used to facilitate the rules and regulations of takäful.

\section{Goal}

The goal of conventional insurance is maximizing profit in favour of shareholders. Insurance companies operate in the interests of businesses and often ignore the interests of their clients. However, the goal of takaful is the well-being of clients and operates by earning minimum profit. In other words, the payment of premiums in takâful are voluntary and rests on the basis of sadaqah rather than individual monetary profits. Ma'sum Billah states that Islamic insurance is merely a policy of joint-guarantee which aims at achieving the pleasure of Allah through the concept of mutual help and co-operation in providing material security for the insured against an unexpected occurrence of risk or loss. ${ }^{40}$ Moreover, the main purpose of takâful is ensuring equity to all parties, and the objective of the contract is to help policyholders in the event of calamities. Hence, profit earning is not the primary goal.

Swartz and Coetzer further elaborated the goal of takāful and said that the person who enter into a takâful scheme should not have intention of making money. Rather, their intention should be sharing wealth with others in the form of tabarru' - a fund that is used to help somebody who requires assistance. Thus, the person should look beyond worldly rewards in the knowledge that when his time comes to face death, the takâful operator, in this perspective, can ease the burden of a person or family during calamities. The goal is pleasing

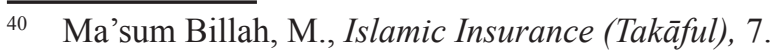


An Analysis of Policy Compatibility Between Conventional Insurance and Islamic Insurance Policies: A Study of Conceptual and Operational Differences

the God and to achieve prosperity in this this world and the hereafter (the day of judgement). ${ }^{41}$

\section{Risk Transfer/Sharing}

Transferring risks and sharing risks are an important aspect of insurance. In conventional insurance, individuals or business enterprises transfer some of their uncertainty risks to the insurer by paying out an amount of money (premium). Insurer in the event of loss compensates the victim (insured) out of this contribution. The insurer's contribution in this system is usually small compared to the amount he or she receives as compensation. Hence, the risk is transferred to the insurer from the insured.

Unlike conventional insurance, risk in takāful is shared by participants. This is because takaful operations are based upon the principles of mutuality whereby each participant makes a donation to a fund. In the event of loss, the participant receives the amount as a support base. Swartz and Coetzer pointed out that the financial responsibilities in takâful scheme are shared in the form of assistance; it provides mutual financial aid and assistance to those who are the members of the takäful scheme. ${ }^{42}$ Thus, takäful is different from conventional insurance system in terms of risk sharing.

\section{Ownership}

Ownership of insurance is another aspect in the comparison between takâful and conventional insurance. The fund in takâful is managed by an operator, however, the participants in takâful are the owners. Thus, they have a complete right of contribution and benefits. However, in conventional insurance, the policyholders purchase the policy from the company, similar to buying a product from a shop; they have no right to determine contributions or benefits. For instance, if a person buys a life insurance policy, he pays the prescribed premium in the contract to the insurance company, which has full control over the amount allocated to the insured.

Thus, in takâful, the policyholders' funds belong to the policyholders on a collective basis and are managed by the shareholders while all the funds in conventional insurance belong to the company which manages it according to their interest.

\footnotetext{
$41 \quad$ Nico P. Swartz \& Pieter Coetzer, 'Takäful: An Islamic Insurance Instrument,' 334.

42 Nico P. Swartz \& Pieter Coetzer, 'Takāful: An Islamic Insurance Instrument,' 334.
} 


\section{Monitoring Committee}

Maintaining a Shariah supervisory committee is compulsory in takāful. This supervisory committee functions as a monitoring mechanism that ensures Shariah compliant operations. ${ }^{43}$ This committee reviews the development of takâful products as well as investments. This committee also carries out independent audits. In other words, the establishment of a Shariah supervisory committee is a prerequisite to all takâful operations prior to commencement. According to the Accounting and Auditing Organisation for Islamic Financial Institutions (AAOIFI), the establishment of a Shariah supervisory committee and an internal auditing system are compulsory. ${ }^{44}$ However, conventional insurance does not maintain any Shariah based internal audit system.

\section{Unlawful Elements}

The conventional insurance system practices Islamically prohibited concepts such as riba (interest), gharar (uncertainty), and maysir (gambling). ${ }^{45}$ The majority of Muslim scholars have decided that the practice and operation of conventional insurance does not fulfil the rules and requirements of Shariah. Therefore, in June 1972, the Malaysian National fatwā Council resolved that conventional insurance was against Islam. ${ }^{46}$ Similarly, the Encyclopaedia of Islamic Banking and Insurance notes that the first international conference for the Islamic economy, held in Makkah in 1976, the Higher Council of Saudi 'Ulamās in 1977, the Fiqh Council of The Muslim World League in 1978 (p. 200) and the Fiqh Academy of the Organization of Islamic Conference (OIC) in December 1985, all held that no form of insurance, life or general, confirmed Islamic principles and therefore was harām (prohibited). ${ }^{47}$

The practices of conventional insurance deemed unlawful by these organisations are the following:

\footnotetext{
43 Ma'sum Billah, M., Islamic and Modern Insurance, 50.

44 Accounting and Auditing Organisation for Islamic Financial Institutions (AAOIFI), Shariah Standards for Islamic Financial Institutions (Bahrain: AAOIFI, 2008), 473.

45 Nasser, Y. \& Jamil, R., Takāful: A Study Guide (Kuala Lumpur: IBFIM, 2011), 81-84.

46 Engku Rabiah Adawiah, E.A., \& Hassan Scott, P.O., Essential Guide to Takāful, 8.

47 Suraiya H., Asnida S., \& Wan Roshidah F., 'The Element of Gambling in Conventional Insurance and Takäful,' (Research Paper, Seminar Ekonomi and Kewangan Islam, University Utara Malaysia, 2012), 199-200.
} 
An Analysis of Policy Compatibility Between Conventional Insurance and Islamic Insurance Policies: A Study of Conceptual and Operational Differences

a) Ribā is translated as 'usury', or exploitative gains made in trade or business. The Qur'ān condemns riba in many places $^{48}$ and described it as a major sin. In essence, rib $\bar{a}$ is the interest earned on the investment of all funds (insurance and shareholders), or advanced fees charged to a policyholder, or credit given out of the insurance business such as loans on the policy or late payments of premium. Razi defines ribā as:

"... a term that is used when two parties exchange item of same kind, and in return one party received extra (or in excess) of what he gave. A simple example is when gives 100 units of Gold and received 120 units of Gold in return. The extra or excess 20 units are considered "rib $\bar{a}$ ". The most common application of ribā is on monetary transaction relating to "loans" and "credits". A simple example of loan is when lender gives $\$ 1000$ to a debtor with an agreement that debtor will return $\$ 1200$ on specified date. Hence, the lender will receive extra $\$ 200$ (either as his service fee, rent, income, or reward for lending money for stated time period). This extra $\$ 200$ is absolute form of ribā in Islamic Shariah. " 49

According to Razi, ribā is extra benefits in exchange for same kind of item in the monetary system and extra money related to loan or credits. The practice of $r i b \bar{a}$ is well entrenched in conventional insurance. The majority of insurance funds are prescribed statutorily to be invested in interest-bearing instruments such as treasury bills, deposits in banks, or interest based loans. ${ }^{50}$ Therefore, conventional insurance operates on the basis of riba $\bar{a}$.

However, in takâful, the investment portfolio as well as other operations of the insurance should not be involved in any of form of ribā-based activities. ${ }^{51}$ Principally, takāful is based on the al-mudāarabah (profit and loss sharing).

b) Gharar (uncertainty) is another difference between conventional and Islamic insurance systems. In conventional insurance, even though the premium payment from the policyholder is certain, the benefit of policyholders from insurance companies is uncertain as it is dependent on unknown future

$\overline{48}$ For example, Surah Āli 'Imrān (3: 130), Surah al-Nisā' (4: 161), Surah al-Rūm (30: 39), Surah al-Baqarah $(2: 275,280)$.

49 Razi, M. 'Ribā in Islam: Fiqh of Contemporary Issues', http://www.kantakji.com/ media/3241/riba-in-islam-v0-4.pdf, accessed 10 January 2017.

50 Mohd Fadzli, Y., Wan Zamri, W.I. \& Abdul Khudus, M.N., Fundamentals of Takāful (Kuala Lumpur: IBFIM, 2011), 62.

51 Engku Rabiah Adawiah, E.A., \& Hassan Scott, P.O., Essential Guide to Takāful, 21. 
disasters during the time of contract. In order to eliminate this aspect, the takâful system has introduced the concept of tabarru' (to donate or give away). The policyholders in this operation agree to relinquish part of the premium to use for mutual help and joint guarantee when one or more members of the company suffer from calamities.

c) Maysir (gambling) is another dimension that differentiates Islamic insurance system from conventional insurance. The policyholder in conventional insurance pays a premium in moderate amounts, however, he or she might be paid a larger amount in the event of loss or calamity. At the same time, he or she will be paid nothing from the premium when not facing any difficulties, as stipulated in the contract. Hence, conventional insurance operates on chance and conjecture.

However, in takâful, tabarru' eliminates this exchange and introduces a cooperative element, making uncertainty irrelevant. In line with this principle of cooperation, participants in this programme agree to give away a certain portion or the whole amount of their contribution into the fund or the common pool. ${ }^{52}$

\section{Contract}

The underlying nature of the contract of conventional insurance is as a sale and purchase for payment of premium. In this arrangement, the insurer provides protection to the insured in the event of calamities, in return for which the insured pays a premium. Since the arrangement is based on a buying-selling contract, the premiums paid by the policyholders form the price or consideration for the protection promised in the policy. ${ }^{53}$

In contrast, the nature of contribution by the participants in a takâful operational model is that of a donation (tabarru') for the purpose of mutual indemnity among all the participants in the plan. The takâful operator is just an agent who has been authorized to operate or manage the takâful fund on behalf of the participants via a wakālah contract of mudārabah, etc. Therefore, the takâful fund and any profit or surplus arising therefrom do not, in principle, belong to the takâful operator; they belong to the takâful participants collectively. The takâful operator cannot take any portion of the contribution,

52 Mohd Fadzli, Y., Wan Zamri, W.I. \& Abdul Khudus, M.N., Fundamentals of Takāful, 18.

53 Engku Rabiah Adawiah, E.A., \& Hassan Scott, P.O., Essential Guide to Takāful, 41. 
An Analysis of Policy Compatibility Between Conventional Insurance and Islamic Insurance Policies: A Study of Conceptual and Operational Differences

except with consent and authorization by the participants. ${ }^{54}$ This factor marks a major difference between conventional insurance and takāful.

\section{Investment}

The contract of takaful provides solidarity in respect to any tragedy and loss to business or property. The policyholders in takâful pay subscriptions to assist and indemnify each other, sharing the profits earned from any business conducted by the company with the subscribed funds. Takaful companies normally divide the contributions into two parts: donations for meeting mortality liability or losses of the fellow policyholders and the other for investments. Accordingly, the clause of tabarru' is incorporated in the contract. How much of the contribution is meant for mortality liability and how much for investments is based on a sound technical basis of mortality tables and other actuarial requirements. Both the accounts are investments and returns thereof are distributed based on the principle mudārabah between the participants and the takâful operators. ${ }^{55}$ To describe this from another angle, a takâful contract may comprise of clauses for either protection or savings/investments or both the benefits of protection as well as savings and investment. The protection part of takâful works on the principle of donation. Accordingly, individual rights are given up to indemnify the losses equally. In the savings part, individual rights remain unharmed under mudārabah and the contributions along with profit (net of expenses) are paid to the policyholders at the end of the term, or before if required.

According to Ma'sum Billah, the distinction between conventional insurance and takäful business is more visible with respect to investment funds. While insurance companies invest their funds in interest-based avenues, takâful companies undertake only Shariah compliant business. The profits are then distributed in accordance with the initially agreed ratios in the contract. ${ }^{56}$

On one hand, takāful is an arrangement of profit-sharing between an insurer and its insured. Takâful insurers are suggested to apply discretion in planning decisions regarding investments and not to focus on potentially high-profit and high-risk situations. Further, takäful insurers desire to maximize higher income from the investment as their recompense is positively connected with

54 Engku Rabiah Adawiah, E.A., \& Hassan Scott, P.O., Essential Guide to Takāful 42.

55 Farooq, S.U., Chaudry, T.S., Fakhr-e-Alam \& Ahmad, G., 'An Analytical Study of the Potential of Takâful Companies', 58.

56 Ma'sum Billah, M., Islamic Insurance (Takāful), 54. 
their own performance. In addition, the principal of investment losses, owing to poor investment performance, should be borne perfectly by the insured. It refers to the existence of a classical principal-agent conflict. For instance, some takâful insurers may invest their funds in the riskiest halal areas and some may invest on the basis of their investment capacity.

\section{Surplus}

Surplus is the remaining amount of money in the insured parties' account. It includes the sum of their paid premiums and their investments after deducting the payments due to them, payment of claims, reinsurance expenses, and payment of fees due to the operator as well as monitoring technical reserves. Insurance surplus is considered one of the main pillars and prominent characteristics of takäful which has been adopted as the core of cooperative insurance based on policyholders' donations and rights.

The policyholders of takâful share any surplus or loss from the pool collectively. Due to surplus money in addition to premium contribution, takâful system has a built-in mechanism to counter any over-pricing policies of the insurance companies. ${ }^{57}$ While in conventional insurance, the premium funds become property of the company and any profits or losses go to the company's account. Accordingly, the insurance company does not share profit or surplus between its members. It provides some yearly bonus and sometime not. Moreover, if no losses are incurred, premiums will not be reimbursed.

The distribution of surpluses among shareholders, operators, and participants is one of the critical issues and challenges within this practice of the Islamic insurance industrial sector. In theory, the principle of surplus delineates that it is the supreme right of participants as this is the remaining of contributions of participants that have not been used within the industry. On the other hand, it is viewed that some of the takâful operators regard the surplus as profit to be distributed among the participants. This situation causes skepticism of validity and is paving the way for us to ask whether it is a supreme principle that the surplus can never be distributed between operators and participants. It is not a supreme rule, because the distribution of surplus by the operators may be featured under some of the principles of Shariah. Perhaps, that is why some of Shariah Boards are subject to sanctioning shareholders to share in the underwriting of surplus with policyholders.

57 Farooq, S.U., Chaudry, T.S., Fakhr-e-Alam \& Ahmad, G., 'An Analytical Study of the Potential of Takäful Companies', 58. 


\section{Forfeiture}

Forfeiture is the involuntary relinquishment of money or property without compensation as a consequence of a breach or non-performance of some legal obligation or due to having committed a crime. In conventional insurance, there is a clause that insurers can forego the premium amount that is paid by the policy holders under certain circumstances. Islam does not allow this sort of sacrifice of the premium, entirely or partially, as the amount of premium is considered as a loan by the insurer to the insured. Thus, in takäful, there is no forfeiture of contributions and it is distributed among the participants in a form of surplus. If the holder of a takâful policy decides to terminate the policy in a manner that is not provided under terms of the contract, the premiums paid by the insurer are refundable to them along with any corresponding opportunity value minus the administrative fees. Hence, forfeiture is another aspect of explaining the differences between takâful and conventional insurance.

\section{Encouragement for Goodness}

Takāful helps people to accumulate their savings for the goodness of the whole community. An opportunity is provided by the takaful scheme to people to practice Islamic law and order. The Prophet Muhammad (PBUH) said:

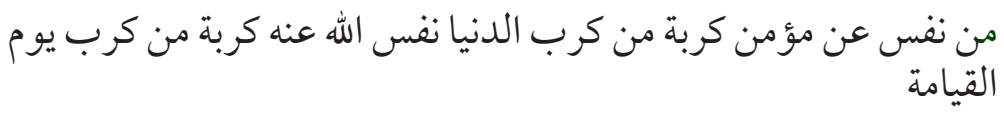

"Whomever relieves a Muslim of distress, Allah will relieve them of distress on the Day of Resurrection..." 58

However, conventional insurance is the opposite.

From the discussion and comparison between takâful and conventional insurance system, the significance of the former, its reliability and competence to face crises are highlighted. Takâful, is far better in terms of solidarity, mutual cooperation, humanity, and brotherhood compare to conventional insurance. Therefore, takâful will grow and enhance its services in the future. However, it is still in the beginning stages of development and it needs a marketing strategy and improvements in order to attract people.

58 Nasiruddin Al Khattab, English Translation of Șaḥh Muslim, vol. 6 (Riyadh: Darussalam, 2007), 447. (6578) 58-2580. 


\section{CONCLUSION}

Muslims all around the world wish to develop along with modern commerce. However, they are not willing to follow non-Islamic practices. They are looking for Islamic alternatives to prevailing financial instruments and practices. Islamic banking is a great success not only in Muslim majority countries but also in Muslim minority countries. Major international banks today are offering Shariah compliant products. In a similar manner, takāful presents an Islamic alternative to insurance.

The interpretations made by scholars provide a complete framework governing takâful. In this study, the suitability of takāful over conventional insurance, along with its applicability in the Muslim world, is discussed. We can say conclusively that Islamic principles can prevent a global financial crisis. Takâful funds are invested in interest-free securities which reduce the chances of crises.

As has been shown, conventional insurance is divergent from takâful. The differences between Islamic and conventional insurance were found mainly in governance and concepts, in the ownership and financing of the company, management, accounting, etc., in which the premiums are invested. However, conventional insurance and takâful were found similar in some of the elements. Both of them are utilized as a protection in the event of unforeseen incidents and the contributions that must be made to start the coverage/insurance.

This study reveals the compatibility of takâful rather than conventional insurance in term of economic and social aspects. In terms of economy, both insured and insurance providers in takâful system benefit and grow together while insurance company only earns in conventional insurance. In terms of social aspect, takâful is beneficial to entire humanity especially to the Muslim community of the world as it promotes mutual trust, cooperation and brotherhood.

To maintain Islamic behaviours, a Muslim may adapt his practices in compliance with Shariah principles. Takäful and conventional insurance models are also different in this regard because of their compatibility with Islamic principles. The conventional model is based on rib $\bar{a}$, gharar and maysir, which are all strictly prohibited in Islam.

\section{RECOMMENDATIONS}

Only the insurance policy precisely delineated, accepted and understood as per the teachings of Islamic principles can be widely practised in this world 
An Analysis of Policy Compatibility Between Conventional Insurance and Islamic Insurance Policies: A Study of Conceptual and Operational Differences

among Muslims. In fact, any individual or business who calls for the Islamic insurance-takâful should possess the proper and sound knowledge to convey the correct Islamic messages and practices on the insurance policy from the Holy Qur' 'an and the teaching of prophet Muhammed (PBUH) - to Muslims and even non-Muslims. From this perspective, the emergence and the practices of the concept of Islamic insurance can be applied to any of the insurance practices and policies in the routine living of the general public. Thus we recommend that Islamic insurance be inclusive of the following: (1) the operation of Islamic banking and finance and (2) the employment of scholars with the sound knowledge of Islamic insurance and to maintain the Islamic law and order. When these two features are adopted, the Muslim community might adapt these practices more readily in compliance with Shariah principles.

\section{REFERENCES}

A.M. Best, Takāful Review (New Jersey: A.M. Best Company Inc., 2013).

Abu-Hussain, M. F., Muhamad, N. H. N. \& Hussain, M. Y. M., 'Takāful (Islamic Insurance) Industry in Malaysia and the Arab Gulf States: Challenges and Future Direction,' Asian Social Science, 10/21 (2014): 26-34.

Accounting and Auditing Organisation for Islamic Financial Institutions (AAOIFI), Shariah Standards for Islamic Financial Institutions (Bahrain: AAOIFI, 2008).

al-Haskafī, A.M.A., Radd al Mukhtār 'alā al-Durr al-Mukhtār Hāshiyah Ibn 'Ābidin, vol. 6 (Beirūt: Dār al-Ma'rifah, 2000).

al-Mundhri, A.A., The Translation of the Meanings of Summarized Sahih Muslim (Riyadh: Darussalam, 2000).

Anscombe, V., 'A Brief History of Insurance throughout the Ages,' Columbus Direct, http://www.columbusdirect.com/content/insurance-history/, accessed 16 December 2016.

Azeem Pirani, 'Takāful: What's it all about?', http:/www.pakqatar.com.pk/ downloads/articles/takaful-what-is-it-all-about.pdf, accessed on 13 June 2014.

Buckham, David, Jason Wahl \& Stuart Rose, Executive's Guide to Solvency II (Cary, North Carolina: SAS Institute Inc., 2010).

Dorfman, M.S., Introduction to Insurance (Englewood Cliffs, USA: Prenticehall, 1978).

Engku Rabiah Adawiah, E.A. \& Hassan Scott, P.O., Essential Guide to Takāful (Islamic Insurance) (Kuala Lumpur: CERT Publications Sdn. Bhd., 2008). 
Farooq, S.U., Chaudry, T.S., Fakhr-e-Alam \& Ahmad, G., 'An Analytical Study of the Potential of Takāful Companies', European Journal of Economics, Finance and Administrative Sciences, 20 (2010): 54-76.

Fowler, F. G., 'Insurance', The Concise Oxford Dictionary of Current English, https://en.oxforddictionaries.com/definition/insurance, accessed 18 December 2016.

Haberbeck, A., 'Risk Sharing in An Islamic Society,' Arab Law Quarterly, 2/2 (1987): 138-147.

Hakim, S. R., 'Islamic Money Market Instruments,' in Handbook of Islamic Banking, (Cheltenham, UK: Edward Elgar Publishing Limited, 2007).

Hansell, D.S. Introduction to Insurance, $2^{\text {nd }} \mathrm{ed}$. (London, UK: LLP., 1999).

Hussein A. Abdou., 'A Comparative Study of Takâful and Conventional Insurance: Empirical Evidence from the Malaysian Market,' Insurance Markets and Companies: Analyses and Actuarial Computations, 4/1 (2014): 23-35.

Ibn Hajar al-'Asqalānī, Fatḥ al-Bārī bi Sharh Ṣaḥ̄h al-Bukhārī, vol. 12 (Cairo, Egypt: Dār al-Hadīth, 2004), 289, 290, no. hadìth 6910.

Institute of Islamic Banking and Insurance, Encyclopaedia of Islamic Banking and Insurance (London: Institute of Islamic Banking and Insurance, 2006).

Investor words, 'Insurance,' http://www.investorwords.com/2510/insurance. html, accessed 6 January 2017.

Jacky Lim, Muhammad Fahmi, I. \& Yura Carissa, 'History, Progress and Future Challenge of Islamic Insurance (Takāful) in Malaysia,' Oxford Business and Economics Conference Program (2010).

Jching, 'MARC's Approach to Rating Institutions Offering Takāful,' MIF Monthly (2008), Takāful Supplement.

Klingmuller, E., 'The Concept and Development of Insurance in Islamic Countries,' Islamic Culture, XLIII (1969).

Ma'sum Billah, M., Islamic and Modern Insurance (Selangor: 'Ilmiah Publishers, 2003).

Ma’sum Billah, M., Islamic Insurance (Takāful) (Selangor: 'Ilmiah Publisher, 2003).

Mahmood, D. N., 'Takāful: The Islamic System of Mutual Insurance,'Arab Law Quarterly, 6/3 (1991).

Mahmoud, 'Insurance: Takāful Gaining Ground,' The Actuary (London: Institute and Faculty of Actuaries, 2008). 
An Analysis of Policy Compatibility Between Conventional Insurance and Islamic Insurance Policies: A Study of Conceptual and Operational Differences

Merazga Hachemi, A.A.M. et al., 'Takāful and Conventional Insurance: A Comparative Study,' International Journal of Management Sciences, 2/12 (2014): 543-551.

Mher Mushtaq H., \& Ahmad Tisman P., 'Conceptual and Operational Differences between General Takāful and Conventional Insurance,' Australian Journal of Business and Management Research, 1/8 (2011): 23-28.

Michael Lipka, 'Muslims and Islam: Key Findings in the U.S. and Around the World,' Pew Research Centre, http://www.pewresearch.org, accessed on 07 February 2017.

Mohd Fadzli, Y., Wan Zamri, W.I. \& Abdul Khudus, M.N., Fundamentals of Takāful (Kuala Lumpur: IBFIM, 2011).

Mohd Shril Matsawali et al., 'A Study on Takâful and Conventional Insurance Preferences: The Case of Brunei,' International Journal of Business and Social Science, 3/22 (Special Issue-November 2012): 163-176.

Mubbsher Munawar Khan et al., 'Comparative Analysis of Islamic and Prevailing Insurance Practices', International Journal of Business and Social Science, 2/10 (2011): 282-286.

Muhammad Anwar, 'Comparative Study of Insurance and Takâful (Islamic Insurance),' The Pakistan Development Review, 33/4, part II (1994): 1315-1330.

Muslehuddin, M., Insurance and Islamic Law, $5^{\text {th }}$ ed. (Lahore: Islamic Publications Ltd., 1990).

Muslim Population, 'Muslim Population in the World,' http://www. muslimpopulation.com/, accessed on 13 July 2017.

Nasiruddin Al Khattab, English Translation of Sahịh Muslim, vol. 6 (Riyadh: Darussalam, 2007).

Nasser, Y. \& Jamil, R., Takāful: A Study Guide (Kuala Lumpur: IBFIM, 2011).

Nico P. Swartz \& Pieter Coetzer, 'Takāful: An Islamic Insurance Instrument,' Journal of Development and Agricultural Economics, 2/10 (2010): 333339.

Obaidullah, Islamic Financial Services (Jeddah, KSA: Islamic Economic Research Centre, King Abdulaziz University, 2005).

Qureshi, A.A., 'Analyzing the Shariah Compliant Issues Currently Faced by Islamic Insurance', Interdisciplinary Journal of Contemporary Research in Business, $3 / 5$ (2011): 279-295. 
Razi, M. 'Ribā in Islam: Fiqh of Contemporary Issues', http://www.kantakji. com/media/3241/riba-in-islam-v0-4.pdf, accessed 10 January 2017.

Redzuan, Rahman \& Aidid, 'Economic Determinants of Family Takāful Consumption: Evidence from Malaysia', International Review of Business Research Papers (2009): 193-211.

Suraiya H., Asnida S., \& Wan Roshidah F., 'The Element of Gambling in Conventional Insurance and Takäful,' (Research Paper, Seminar Ekonomi and Kewangan Islam, Universiti Utara Malaysia, 2012), 199-210.

Tobias F. \& Younes S., Takäful \& Retakäful: Advanced Principles and Practices (Kuala Lumpur: IBFIM, 2010).

Umar Chopra, M., The Islamic Welfare State and its Role in the Economy (Leicester: The Islamic Foundation, 1979). 